\title{
The Impact of Biopreparations and Sowing Dates on the Productivity of Fennel (Foeniculum vulgare Mill.)
}

\author{
Olga Makukha' \\ 1 Kherson State Agricultural University, Stritenska Street 23, 73006, Kherson, Ukraine \\ e-mail:olga_ovm@ukr.net, olgaovm19@gmail.com
}

\begin{abstract}
Fennel (Foeniculum vulgare Mill.) is a valuable medicinal and aromatic plant. The introduction of such an ecofriendly element as presowing seeds inoculation with phosphate mobilizing microbial biopreparation into the growing technology is especially important in the cultivation of this crop. It is connected with an extensive use of fennel in the production of medicines, including the remedies for children. Under the moisture deficiency conditions of the southern Steppe of Ukraine, the study on the effectiveness of phosphate mobilizing biopreparations depending on the impact of sowing dates is particularly relevant. Our field experiments were carried out in 2017-2019 in the Kherson region on the dark chestnut soils typical for the southern Steppe of Ukraine. Presowing seeds inoculation with biopreparations of phosphate mobilizing bacteria Albobakteryn and Polimiksobakteryn positively affected the indicators of fennel productivity and yield quality. Among the microbial preparations studied, a preference for Polimiksobakteryn was recorded. The research findings indicate a tendency to lower the quantitative and qualitative indicators of fennel seed yield from early to late sowing. The most favourable conditions for the productive processes of fennel plants and accumulation of essential oil were ensured by the interaction of seeds bacterization with the Polimiksobakteryn biopreparation and early spring sowing at the right soil tilth stage in the third ten-day period of March. In this variant, the yielding capacity was $1.41 \mathrm{t} / \mathrm{ha}$, the weight of 1000 seeds reached $5.61 \mathrm{~g}$, the essential oil content in the seeds amounted to $6.13 \%$ in dry matter, the relative yield of essential oil being $76.1 \mathrm{~kg} / \mathrm{ha}$. The introduction of microbial preparations of phosphate mobilizing bacteria into the technology of fennel cultivation is a promising environmentally friendly approach to improving the crop productivity.
\end{abstract}

Keywords: fennel, biopreparations of phosphate mobilizing bacteria, presowing seeds inoculation, Albobakteryn, Polimiksobakteryn, sowing dates, seed yield, essential oil content in seeds.

\section{INTRODUCTION}

Foeniculum vulgare Mill., universally known as fennel, is a medicinal and aromatic plant belonging to the Apiaceae (Umbelliferae) family. All parts of the plant such as root, stem, leaves and especially seeds are aromatic and can be used in many ways [Badgujar et al. 2014]. The valuable properties of fennel plant are due to its different chemical compounds [Kooti et al. 2015]. Phenols, phenolic glycosides and volatile aroma compounds such as trans-anethole, estragole and fenchone have been reported as the major phytoconstituents of this species. The phenolic compounds isolated from fennel are considered to be responsible for its antioxidant activity while the volatile aroma compounds make it an excellent flavouring agent [Rather et al. 2016].

Fennel is a traditional and popular herb with a long history of use as a medicine for a wide range of ailments related to the digestive, endocrine, reproductive, and respiratory systems [Badgujar et al. 2014]. Its seeds and essential oil are also widely used as flavouring agents in the food industry and as ingredients of cosmetics and pharmaceutical products [Akbar 2018]. Fennel is used in many of the culinary traditions of the world [Rather et al. 2016]. It is one of the oldest spice plants [Kooti et al. 2015]. Fennel originated in the southern Mediterranean region [Krishnamurthy 2011]. It has now been naturalized and cultivated for commercial purposes throughout the world 
[Al-Snafi 2018]. Foeniculum vulgare is one of the most commonly used and extensively studied medicinal herbs in the world due to its economic importance and significant pharmaceutical industry applications. Multitudinous health benefits are reported by many researchers [Kooti et al. 2015, Syed et al. 2019]. In resent years, increased interests in the improvement of agricultural yield of fennel due to its medicinal properties and essential oil content has encouraged the cultivation of the plant on large scale [Badgujar et al. 2014].

In Ukraine, fennel is traditionally grown in temperate climates in the western regions. Since 2011, a scientific research and its introduction into cultivation under arid conditions in the southern Steppe of Ukraine have been conducted. The cultivation of this promising, highly profitable crop, even on small areas, will significantly improve the performance of the agricultural enterprises in the region, especially farms [Makukha et al. 2018]. A successful cultivation of fennel requires the scientific improvement of the growing technology, taking into account the soil-climatic conditions of the zone and their effect on the plants.

One of the urgent problems of modern agriculture of Ukraine is to optimize the phosphorus nutrition of crops, which is due to the important role of phosphorus in the crop production process and the low natural content of its mobile compounds in soils [Volkohon et al. 2015]. Worldwide, phosphorus is the second most commonly used plant nutrient in agriculture after nitrogen. Phosphorus plays a key role in nearly all plant metabolic processes, including photosynthesis, respiration, and energy transfer [Khan et al. 2010, Sharma et al. 2013].

Although phosphorus is abundant in soils both in the inorganic and organic forms, it is a major limiting factor for the plant growth [Rengel and Marschner 2005]. In most agricultural soils, a large quantity of phosphorus has accumulated as a consequence of intensive phosphorus fertilization, but only $0.1 \%$ of the total phosphorus is present in a soluble form available for the root uptake [Zhou et al. 1992]. A decreasing response in the crop yield with increasing soil phosphorus status has been observed, making the application of chemical phosphorus fertilizers, especially in well-fertilized European soils, increasingly inefficient and uneconomical [Schoumans et al. 2015].

The majority of the applied fertilizer phosphorus is not available to plants. The addition of inorganic fertilizers in excess of the amount that is commonly employed to overcome this effect can lead to environmental problems, such as groundwater contamination, eutrophication of surface waters, the loss of soil fertility by disturbing microbial diversity. Increased phosphorus levels exert adverse environmental impacts on the overall soil health and degradation of terrestrial, freshwater and marine resources [Kang et al. 2011, Sharma et al. 2013]. Furthermore, phosphorus is a finite resource and based on its current rate of use, it has been estimated that the world's known reserves of high quality phosphate rock may become depleted within the current century [Cordell et al. 2009].

The inoculation of soil or crop with phosphate-solubilizing microorganisms is therefore a promising strategy for the improvement of the plant absorption of phosphorus and thereby reducing the use of chemical fertilizers that have a negative impact on the environment. The use of microbial inoculants characterized by phosphatesolubilizing activities in agricultural soils is considered as environmentally friendly supplement or an alternative to further applications of the chemical based phosphorus fertilizers. However, there is a need to develop the phosphate solubilizing technologies specific to various regions, crops and their varieties, different strains of microorganisms [Sharma et al. 2013, Alori et al. 2017].

The introduction of such eco-friendly element as seeds inoculation with phosphate mobilizing microbial biopreparation into growing technology is especially important in the cultivation of fennel. It is connected with an extensive use of fennel in the production of medicines, including the remedies for children, and, as a consequence, with increased requirements for the quality and environmentally friendliness of raw materials. Under the moisture deficiency conditions of the southern Steppe of Ukraine, the study on the effectiveness of phosphate mobilizing biopreparations depending on sowing dates that indirectly influence the moisture supply of fennel sprouts, as well as affect the hydrothermal environment of the phases of growth and development, is particularly relevant.

\section{MATERIALS AND METHODS}

The field experiments were carried out in the period from 2017 to 2019 on the fields of Dawn farm of Vysokopillia district in Kherson region 
(latitude 47'27'47'N and longitude 33'13'34'E). The study was devoted to determining the effect of presowing seeds bacterization with the phosphate mobilizing biopreparations and sowing dates on the crop productivity and quality indicators of the fennel yield under the arid conditions of the southern Steppe of Ukraine.

The experimental design included the following factors and their variants: Factor A - presowing seeds inoculation with biopreparations: without inoculation (control); inoculation with Albobakteryn; inoculation with Polimiksobakteryn; Factor B - sowing date: early (the third tenday period of March at the right soil tilth stage); mid-time (the first ten-day period of April); late (the second ten-day period of April). The field experiments were carried out in accordance with the generally accepted requirements and recommendations [Dospehov 1985, Yeshchenko et al. 2014]. The trial was based on a split plot method with a four-fold replication. The sown area of the second-order elementary plot was $70 \mathrm{~m}^{2}$; the record plot was $55 \mathrm{~m}^{2}$.

The objectives of the present study were microbial preparations Albobakteryn and Polimiksobakteryn, based on the active strains of the phosphate mobilizing bacteria. These biopreparations were elaborated in the Institute of Agricultural Microbiology and Agroindustrial Production NAAS (Chernihiv, Ukraine) for the improvement of phosphate nutrition of crops. The active ingredient of Albobakteryn involves the phosphate mobilizing bacteria Achromobacter album 1122, Polimiksobakteryn - Paenibacillus polymyxa $K B$. The biopreparations enhance the availability of phosphorus for plants, stimulate their growth and development, increase the crop productivity, improve the quality traits of yield, and protect plants against the influence of stress factors, phytopathogens.

In the experiment, the inoculation of fennel seeds with microbial preparations Albobakteryn and Polimiksobakteryn was conducted the day before sowing. Harvesting and yield registration, determining the weight of 1000 fennel seeds were done according to the relevant methods [Yeshchenko et al. 2014]. The content of essential oil in seeds was determined with the method of Ginsberg [DSTU 7109:2009]. The soil of the experimental plot is dark chestnut weakly alkaline medium loamy, typical for the southern steppe zone of Ukraine. The arable layer of the soil contains humus (2.31\%), nitrates (26), movable phosphorus (29), and exchangeable potassium (240 mg/kg of soil).

The climate of the zone is moderately continental, hot and dry, characterized by low and unevenly distributed precipitation, low air humidity, frequent droughts and strong dry winds, a lot of heat and light. The sum of active temperatures above $10^{\circ} \mathrm{C}$ is $3200-3400^{\circ} \mathrm{C}$, average annual precipitation is $340-400 \mathrm{~mm}$, and the hydrothermal coefficient is $0.5-0.7$. The weather conditions during the years of research differed somewhat in the temperature regime, amount and distribution of atmospheric precipitation, but overall were typical for the zone.

The generally accepted agricultural practices of fennel cultivation were used, except for the factors and variants studied. Winter wheat was the preceding crop in the experiment. The authors applied $60 \mathrm{~kg}$ of the active ingredient of ammonium sulphate per ha. The seeding rate was $5 \mathrm{~kg} /$ ha, row spacing $-45 \mathrm{~cm}$, seeding depth $-2-3 \mathrm{~cm}$. The fennel seeds were harvested when the fruits reached maturity on the central umbel and firstorder umbels.

\section{RESULTS AND DISCUSSION}

The results of the studies showed that the presowing seeds treatment with the biopreparations of phosphate mobilizing bacteria and the dates of sowing are important agrotechnical measures for managing the productivity of common fennel. The effectiveness of microbial preparations under investigation varied depending on their type and the impact of seeding dates.

The yielding capacity of the fennel seeds was 0.97-1.41 t/ha, depending on the interaction of the studied elements of the growing technology. The minimum value of this character $(0.97 \mathrm{t} / \mathrm{ha})$ was recorded after sowing without seeds inoculation in the second ten-day period of April. The most favourable conditions for the crop productivity at $1.41 \mathrm{t} /$ ha were provided by the interaction of the following parameters of the investigated technological practices: presowing seeds bacterization with the Polimiksobakteryn phosphate mobilizing biopreparation, early spring planting in the third ten-day period of March (Table 1).

The mean factor value of the fennel seed yield in the control variant (without inoculation) was $1.09 \mathrm{t} / \mathrm{ha}$. Presowing seeds bacterization with Albobakteryn led to an increase of this indicator, on 
Table 1. Seed yield of fennel depending on the factors under study, $t /$ ha (average for 2017-2019)

\begin{tabular}{|l|c|c|c|c|}
\hline \multirow{2}{*}{$\begin{array}{c}\text { Seeds inoculation with biopreparations, } \\
\text { factor A }\end{array}$} & \multicolumn{3}{|c|}{ Sowing date, factor B } & \multirow{2}{*}{ Average for factor A } \\
\cline { 2 - 5 } & early & mid-time & late & 1.09 \\
\hline Without inoculation (control) & 1.24 & 1.06 & 0.97 & 1.17 \\
\hline Albobakteryn & 1.35 & 1.13 & 1.02 & 1.21 \\
\hline Polimiksobakteryn & 1.41 & 1.17 & 1.04 & 1.15 \\
\hline Average for factor B & 1.33 & 1.12 & 1.01 & \\
\hline
\end{tabular}

average, by $7.3 \%$, Polimiksobakteryn $-11.0 \%$ compared to the control (without inoculation).

The degree of effect of the microbial preparations on the seed productivity of common fennel reduced from early to late sowing. It may be connected with the changes in the conditions of moisture supply and temperature regime.

The seeds treatment with Albobakteryn caused an $8.9 \%$ increase of yield compared to the control in the variant of early spring planting. When sown by one and two ten-day periods later, the above mentioned index was 6.6 and 5.2\%, respectively. The yield increase under the influence of the Polimiksobakteryn microbial preparation, in comparison with the control reduced from $13.7 \%$ on early-sown plots to $7.2 \%$ in the variant of late spring planting.

The mean factor value of the yielding capacity of $1.33 \mathrm{t} /$ ha was recorded under sowing in the third ten-day period of March. On the experimental plots of mid sowing time, there was a $15.8 \%$ reduction in the crop productivity compared to early seeding; this reduction was $24.1 \%$ in the late-sown variants. The research results indicate a preference for early spring sowing in the third ten-day period of March among the seeding dates studied. Postponing sowing to the first-second decade of April led to a decrease in the yielding capacity of fennel. In addition, creating favorable conditions for implementing the potential of biological effectiveness of investigated phosphate mobilizing microbial preparations was provided by early spring fennel seeding.

Postponed sowing, which is accompanied by loss of moisture from the surface layer of the soil, can adversely affect the formation of fennel sprouts and further development of the crop. With a delay in sowing, there is deterioration in the conditions for the productive processes of plants under the influence of a more intensive increase in the sum of effective temperatures, the negative impact of the summer drought on the flowering and fruits formation, and that of autumn rains on maturing [Makukha et al. 2018]. The problem of high-quality seeds is especially timely in the cultivation of common fennel. It is connected with a stable demand for the planting material due to the local scale of sown areas, the morphological and biological characteristics of fennel seeds such as dense hull, small size, and low germinating capacity compared to other crops. Larger seeds are characterized by better sowing qualities, which may be due to a better embryo development and accumulation of more nutrients [Makukha 2019].

The range of variation in the weight of 1000 fennel seeds, depending on the phosphate mobilizing biopreparations and sowing dates, was 4.43-5.61 g. The minimum value of this character was obtained on the experimental plots after late spring sowing in the second ten-day period of April without inoculation. The highest level of the investigated index was recorded in the variant of the interaction of presowing seeds treatment with the Polimiksobakteryn microbial preparation and early spring planting in the third ten-day period of March (Fig. 1).

On average, by factor A, when sowing was done without a preliminary seeds bacterization, the parameter under study was $4.85 \mathrm{~g}$. The seeds inoculation with Albobakteryn led to an increase in this index compared to the control by $3.3 \%$, the seeds treatment with Polimiksobakteryn resulted in a $4.5 \%$ increase. The growth of the studied parameter under the influence of the microbial preparations Albobakteryn and Polimiksobakteryn was minimal in the variants of late sowing and reached 2.5 and $3.2 \%$, respectively. An increase in the weight of 1000 fennel seeds depending on the above mentioned phosphate mobilizing biopreparations reached the highest value on the early sown plots and made up 3.9 and $5.5 \%$, respectively.

When fennel was sown in the third ten-day period of March, the mean factor value of the mass of 1000 seeds amounted to $5.49 \mathrm{~g}$. The investigated indicator reduced when seeding was 


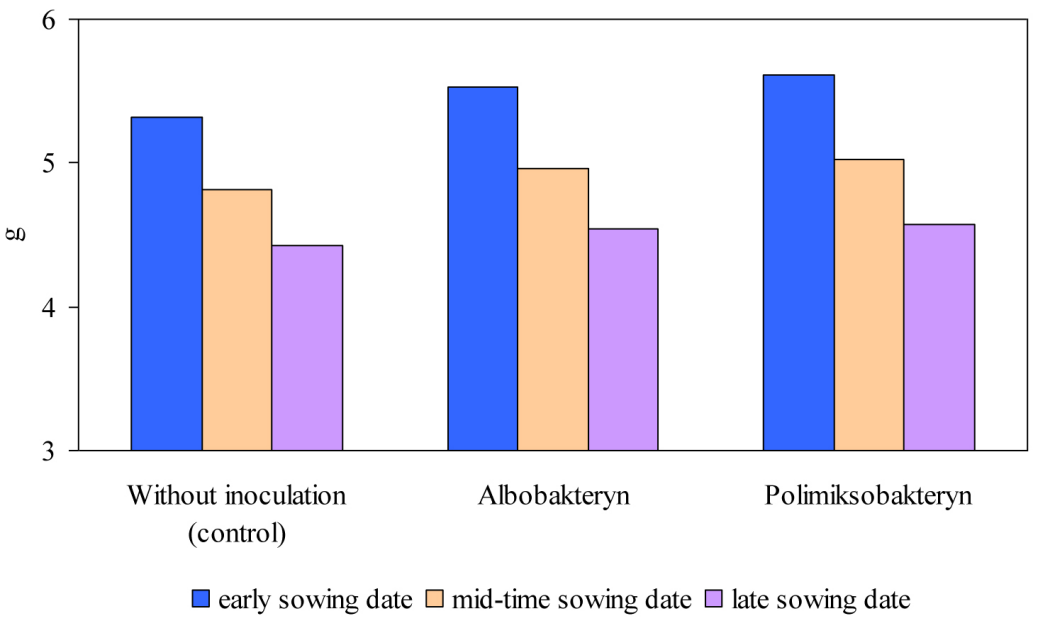

Figure 1. Weight of 1000 seeds of fennel depending on the factors under study (average for 2017-2019)

postponed by one and especially two ten-day periods compared to the early dates. In the midsown and late variants, this parameter was lower by 10.2 and $17.9 \%$, respectively. The content of essential oil in seeds and its relative yield from 1 hectare of the crop area are important qualitative indicators in the cultivation of common fennel.

The mass fraction of essential oil in fennel seeds changed in the context of variants from 5.37 to $6.13 \%$ in dry matter and made up, on average, by the experiment, $5.71 \%$. The least favourable conditions for the accumulation of essential oil in fennel fruits at a level of $5.37 \%$ in dry matter were obtained on the plots of late sowing without seeds inoculation with the biopreparations of phosphate mobilizing bacteria. In the variant of the interaction of presowing seeds treatment with Polimiksobakteryn and early-time planting in the third ten-day period of March, the maximum value of the investigated index $-6.13 \%$ in dry matter was recorded (Fig. 2).

Seeds inoculation with microbial preparations positively affected the content of essential oil in fennel fruits. On average, the bacterization of seeds with Albobakteryn resulted 1.03fold increase of this indicator compared to the control. When the fennel seeds were inoculated with Polimiksobakteryn, the studied parameter increased, by a factor, of 1.04. The most effective interaction of the agrotechnical practices under investigation was observed in the variant of early plant sowing after the bacterization of seeds with Polimiksobakteryn. In this version, the increase of the essential oil content in the fennel seeds compared to the control was maximal and amounted to $0.29 \%$.

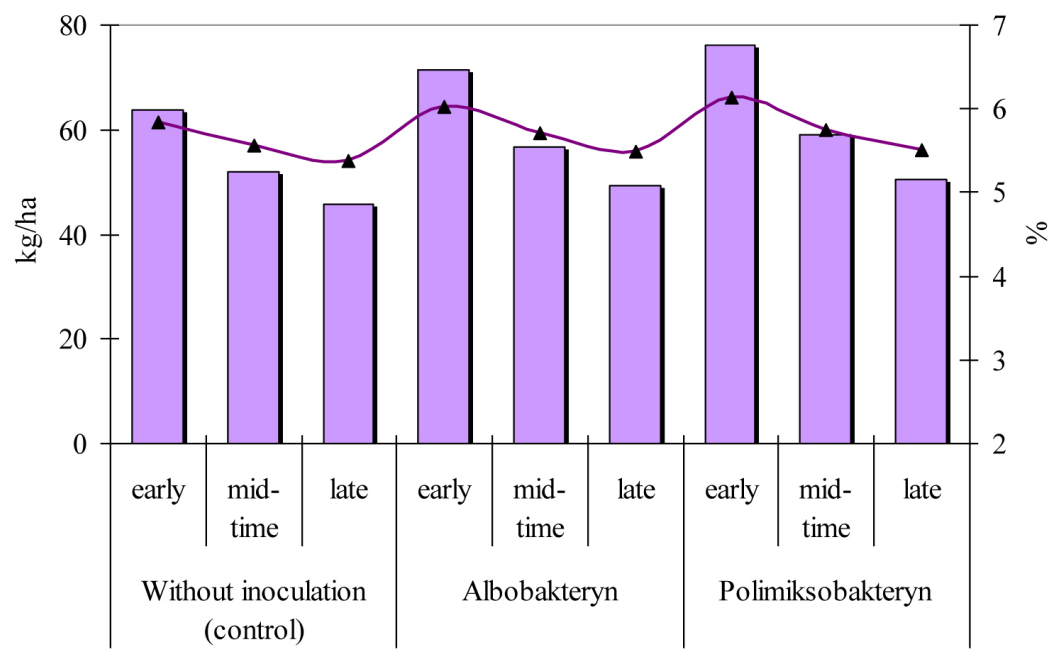

$\square$ relative yield of essential oil, $\mathrm{kg} / \mathrm{ha} \multimap$ essential oil content in seeds, \%

Figure 2. Content in seeds and relative yield of essential oil of fennel depending on the factors under study (average for 2017-2019) 
The analysis of the sowing periods under study revealed a clear preference for seeding in the third ten-day period of March. The sowing one-two ten-day periods later caused 1.06-1.10fold decrease in the content of essential oil in the seeds of the crop. The relative yield of essential oil from 1 hectare of the crop area, as an integral index, reflected the basic patterns of the influence of the investigated factors on the seeds yielding capacity and content of essential oil in the fennel seeds. This indicator allows evaluating the effectiveness characterizing different variants of the interaction of technological practices under study in the context potentially using fennel seeds as a raw material for the production of essential oil.

The minimum level of the relative yield of essential oil of common fennel $(45.8 \mathrm{~kg} / \mathrm{ha})$ was recorded on the experimental plots of sowing in the second ten-day period of April without the seeds inoculation with microbial preparations. This enabled reaching the highest value of $76.1 \mathrm{~kg} / \mathrm{ha}$ in the variant of early spring sowing after seeds treatment with phosphate mobilizing biopreparation Polimiksobakteryn (Fig. 2).

On the plots after presowing seeds bacterization with Albobakteryn, there was a 7.6-12.2\% increase of the relative yield of essential oil compared to the control variant (without inoculation). A $10.0-19.5 \%$ increase in the investigated indicator was observed under the influence of Polimiksobakteryn. The lowest values of the above mentioned ranges of variation in this parameter were observed after seeding in the second tenday period of April. The maximum values were ensured by early spring sowing. In the mid-sown variant, the relative yield of essential oil was lower compared to the early seeding by $18.5-22.3 \%$ depending on the influence of microbial preparations. Postponing sowing from the third ten-day period of March to the second ten-day period of April resulted in a 28.1-33.8\% decrease.

Microorganisms play a fundamental role in mobilizing the inorganic and organic phosphorus in the soil and the rhizosphere [Adhya et al. 2015]. The phosphate solubilizing microorganisms act as biofertilizers by making unavailable phosphorus available to growing plants [Wani et al. 2007]. They increase the phosphorus uptake by the plants [Gupta et al. 2014]. The overall contribution associated with phosphorus nutrition to plants includes root development, stalk and stem strength and growth, formation of flowers and seeds, resistance to plant diseases, crop quality, maturity and productivity [Thakur et al. 2014]. Phosphorus is important in every aspect, from the molecular level to plant development [Satyaprakash et al. 2017].

The phosphate solubilizing bacteria may also aid the growth of plants by stimulating the efficiency of biological nitrogen fixation, synthesizing phytohormones and enhancing the availability of some trace elements such as zinc and iron. These microorganisms demonstrate potential as biocontrol agents against some plant pathogens. The phosphate solubilizing microorganisms improve the growth and yield of a wide variety of crops [Alori et al. 2017]. Root colonizing Bacillus and Paenibacillus strains are well known for enhancing the growth of plants [Gupta et al. 2014].

The results of numerous studies show that the phosphate solubilizing microorganisms have a considerable synergistic effect on the growth and development of such crops as radish [Lara et al. 2013], wheat, mung bean, sweetleaf, Chinese cabbage, rice, maize, soybean, beans [Alori et al. 2017], and tomato [Nassal et al. 2018].

The application of the phosphate solubilizing bacteria, Bacillus sp., enhanced the growth and yield of cotton and sunflower under field conditions [Ekin 2010, Qureshi et al. 2012]. A significant increase in grain yield was reported for rice, chickpea, lentil, soybean and cowpea when Pseudomonas striata, Aspergillus awamori and Bacillus polymyxa were used either alone or in combination [Sashidhar and Podile 2010].

The research results indicate the effect of the inoculation with the phosphate solubilizing microorganisms on the productivity of wheat, sesame, and soybean plants [Jahan et al. 2013, Mahanta et al. 2014]. The use of Polimiksobakteryn improves the phosphorus nutrition of winter wheat and promotes the increase in the yield of this crop [Volkohon et al. 2015]. A clear tendency of positive influence of the phosphate mobilizing bacteria on the fennel productivity revealed in our study was similar to the scientific results obtained by many researchers with other crops.

In the field studies, the phosphate solubilizing microorganisms had an inconsistent effect on the growth and yield of crops. The variable response of plant species or genotypes to inoculation depended on the bacterial strain used, soil conditions, environmental factors affecting the survival and colonization of the rhizosphere [Khan et al. 2007, Adhya et al. 2015]. 
The changes in the biological activity of the phosphate mobilizing bacteria confirms the relevance of scientific investigations on the impact of biopreparations on the seed productivity of common fennel, taking into account the specific soil-climatic conditions of the southern Steppe of Ukraine. Increasing the effectiveness of the microbial biopreparations under study is connected with the improvement of the sowing dates of fennel that influence the moisture supply and temperature regime of growth and development of the crop. Introduction of efficient agronomic managements will ensure delivery and survival of inoculants [Adhya et al. 2015].

\section{CONCLUSIONS}

The presowing seeds inoculation with the biopreparations of the phosphate mobilizing bacteria positively affected the indicators of fennel productivity and yield quality. Among the microbial preparations studied, a preference for Polimiksobakteryn was recorded. The research findings indicate a tendency to lower the quantitative and qualitative indicators of fennel seed yield from early to late sowing. The most favourable conditions for the productive processes of fennel plants and accumulation of essential oil were ensured by the interaction of seeds bacterization with the Polimiksobakteryn biopreparation and early spring sowing at the right soil tilth stage in the third ten-day period of March. The introduction of microbial preparations of the phosphate mobilizing bacteria into the technology of fennel cultivation is a promising and environmentally friendly approach to improving the crop productivity.

\section{REFERENCES}

1. Adhya T. K., Kumar N., Reddy G., Podile A. R., Bee H., Samantaray B. 2015. Microbial mobilization of soil phosphorus and sustainable P management in agricultural soils. Current Science, 108 (7), 1280-1287.

2. Akbar S. 2018. Fennel (Foeniculum vulgare Mill.): A Common Spice with Unique Medicinal Properties. Annals of Complementary and Alternative Medicine, 1 (1), Article 1001, 1-9.

3. Alori E. T., Glick B. R., Babalola O. O. 2017. Microbial Phosphorus Solubilization and Its Potential for Use in Sustainable Agriculture. Frontiers in Microbiology, 8, Article 971, 1-8.
4. Al-Snafi A. E. 2018. The chemical constituents and pharmacological effects of Foeniculum vulgare - A review. IOSR Journal of Pharmacy, 8 (5), 81-96.

5. Badgujar S. B., Patel V. V., Bandivdekar A. H. 2014. Foeniculum vulgare Mill.: A Review of Its Botany, Phytochemistry, Pharmacology, Contemporary Application, and Toxicology. BioMed Research International, Vol. 2014, Article ID 842674, 1-32.

6. Cordell D., Drangert J. O., White S. 2009. The story of phosphorus: global food security and food for thought. Glob Environ Chang, 19, 292-305.

7. Dospehov B. A. 1985. Field experiment method. Agropromizdat, Moscow (in Russian).

8. DSTU 7109:2009. 2011-01-01. Fruits of essential oil crops for industrial processing. Methods for determining the mass fraction of essential oil (National Standard of Ukraine). Derzhspozhyvstandart Ukrainy, Kyiv (in Ukrainian).

9. Ekin Z. 2010. Performance of phosphate solubilizing bacteria for improving growth and yield of sunflower (Helianthus annuus L.) in the presence of phosphorus fertilizer. African Journal of Biotechnology. 9 (25), 3794-3800.

10. Gupta G. N., Srivastava S., Khare S. K., Prakash V. 2014. Role of Phosphate Solubilizing Bacteria in Crop Growth and Disease Management. Journal of Pure and Applied Microbiology, 8 (1), 461-474.

11. Jahan M., Mahallati M. N., Amiri M. B., Ehyayi H. R. 2013. Radiation absorption and use efficiency of sesame as affected by biofertilizers inoculation in a low input cropping system. Industrial Crops and Products, 43, 606-611.

12. Kang J., Amoozegar A., Hesterberg D., Osmond D. L. 2011. Phosphorus leaching in a sandy soil as affected by organic and incomposted cattle manure. Geoderma, 161, 194-201.

13. Khan M. S., Zaidi A., Ahemad M., Oves M., Wani P. A. 2010. Plant growth promotion by phosphate solubilizing fungi-current perspective. Archives of Agronomy and Soil Science, 56 (1), 73-98.

14. Khan M. S., Zaidi A., Wani P. A. 2007. Role of phosphate-solubilizing microorganisms in sustainable agriculture - A review. Agronomy for Sustainable Development, 27, 29-43.

15. Kooti W., Moradi M., Ali-Akbari S., Sharafi-Ahvazi N., Asadi-Samani M., Ashtary-Larky D. 2015. Therapeutic and pharmacological potential of Foeniculum vulgare Mill.: a review. Journal of HerbMed Pharmacology, 4 (1), 1-9.

16. Krishnamurthy K. H. 2011. Medicinal plants: Madhurika, saunf or fennel (Foeniculum vulgare, Gaertn). Journal of New Approaches to Medicine and Health, 19 (1), 1-4.

17. Lara C., Sanes S. C., Oviedo L. E. 2013. Impact of native phosphate solubilizing bacteria on the growth 
and development of radish (Raphanus sativus L.) plants. Biotecnologia Aplicada, 30, 276-279.

18. Mahanta D., Rai R.K., Mishra S.D., Raja A., Purakayastha T.J., Varghese E. 2014. Influence of phosphorus and biofertilizers on soybean and wheat root growth and properties. Field Crops Research, 166, 1-9.

19. Makukha O. 2019. The Impact of Row Spacing on the Productivity of Common Fennel Varieties (Foeniculum vulgare Mill) under the Conditions of the Southern Steppe of Ukraine. Research Journal of Pharmaceutical, Biological and Chemical Sciences, 10 (2), 582-591.

20. Makukha O., Markovska O., Mynkina H., Chernyshova Y. 2018. The Impact of Seeding Dates and Depth on the Productivity of Common Fennel (Foeniculum vulgare Mill.) under the Conditions of the Southern Steppe of Ukraine. Research Journal of Pharmaceutical, Biological and Chemical Sciences, 9 (6), 1075-1083.

21. Nassal D., Spohn M., Eltlbany N., Jacquiod S., Smalla K., Marhan S., Kandeler E. 2018. Effects of phosphorus-mobilizing bacteria on tomato growth and soil microbial activity. Plant Soil, 427, 17-37.

22. Qureshi M.A., Ahmad Z.A., Akhtar N., Iqbal A., Mujeeb F., Shakir M.A. 2012. Role of phosphate solubilizing bacteria (PSB) in enhancing $\mathrm{P}$ availability and promoting cotton growth. The Journal of Animal \& Plant Sciences, 22 (1), 204-210.

23. Rather M.A., Dar B.A., Sofi S.N., Bhat B.A., Qurishi M.A. 2016. Foeniculum vulgare: A comprehensive review of its traditional use, phytochemistry, pharmacology, and safety. Arabian Journal of Chemistry, 9, 1574-1583.

24. Rengel Z., Marschner P. 2005. Nutrient availability and management in the rhizosphere: exploiting genotypic differences. New Phytology, 168, 305-312.

25. Sashidhar B., Podile A.R. 2010. Mineral phosphate solubilization by rhizosphere bacteria and scope for manipulation of the direct oxidation pathway involving glucose dehydrogenase. Journal of Applied
Microbiology, 109, 1-12.

26. Satyaprakash M., Nikitha T., Reddi E. U. B., Sadhana B., Satya Vani S. 2017. Phosphorus and Phosphate Solubilising Bacteria and their Role in Plant Nutrition. International Journal of Current Microbiology and Applied Sciences, 6 (4), 2133-2144.

27. Schoumans O. F., Bouraoui F., Kabbe C., Oenema O., Dijk K. C. 2015. Phosphorus management in Europe in a changing world. Ambio, 44 (2), 180-192.

28. Sharma S.B., Sayyed R.Z., Trivedi M.H., Gobi T.A. 2013. Phosphate solubilizing microbes: sustainable approach for managing phosphorus deficiency in agricultural soils. SpringerPlus, 2 (587), 1-14.

29. Syed F.Q., Mirza M.B., Elkady A.I., Hakeem K.R., Alkarim S. 2019. An Insight of Multitudinous and Inveterate Pharmacological Applications of Foeniculum vulgare (Fennel): Pharmacology and Therapeutic Uses. Plant and Human Health, 3 (11), 231-250.

30. Thakur D., Kaushal R., Shyam V. 2014. Phosphate solubilising microorganisms: role in phosphorus nutrition of crop plants - a review. Agri. Review, 35 (3), 159-171.

31. Volkohon V.V., Tokmakova L.M., Kovpak P.V., Trepach A.O., Lepeha O.P. 2015. Phosphate nutrition and yield of winter wheat under the influence of fertilizers and Polimiksobakteryn. Agricultural Science and Practice, 2 (2), 3-8.

32. Wani P.A., Khan M.S., Zaidi A. 2007. Co-inoculation of nitrogen fixing and phosphate solubilizing bacteria to promote growth, yield and nutrient uptake in chickpea. Acta Agron. Hung., 55, 315-323.

33. Yeshchenko V.O., Kopytko P.H., Kostohryz P.V., Opryshko V.P. 2014. Foundations of scientific investigations in agronomy: textbook. Edelveis i K, Vinnytsia (in Ukrainian).

34. Zhou K., Binkley D., Doxtader K. G. 1992. A new method for estimating gross phosphorus mineralization and immobilization rates in soils. Plant and Soil, 147, 243-250. 